\title{
AS NOVAS TECNOLOGIAS E A APRENDIZAGEM
}

\section{Moran, J. .M., Masetto, M. T. \& Behrens, M. A. (2000). Novas Tecnologias e Mediação Pedagógica. Ed. Papirus. falta número de páginas}

$\mathbf{E}_{\text {stamos presenciando o investimento cada vez }}$ maior feito pelas instituições de ensino em tecnologias telemáticas de alta velocidade para conectar professores e alunos no ensino presencial e à distância. A visão de que a tecnologia amplia o conceito de aula, de espaço e de tempo é cada vez mais difundida.

Neste contexto, Moran enfoca, no primeiro capítulo, as influências que o cotidiano, com suas mudanças constantes, vem trazendo para a educação. Esta é apresentada como o caminho fundamental para transformar a sociedade.

$\mathrm{Na}$ era da informação, a transição de modelos e padrões de ensino impõe desafios a serem enfrentados por quem ensina e quem aprende. Ensinar é diferenciado de aprender neste capítulo pela definição de que ensinar é um processo social, no qual cada um desenvolve um estilo próprio, dentro do que é traçado para todo o grupo. Educar já é considerado como a colaboração que se tem para que professores e alunos transformem suas vidas em processos permanentes de aprendizagem.

Para este autor, o ensino de qualidade envolve uma escola que tenha espaços e materiais adequados ao desenvolvimento das atividades didáticas, professores bem preparados e alunos motivados.

De modo geral, ele trata a questão da informação sendo transformada em conhecimento neste ambiente e estilo de aprendizagem. A aprendizagem na era da informação pode ser facilitada pelo uso da tecnologia como recurso didático, o que exigirá do professor mudança de papel, passando a ser um facilitador do aluno na interpretação e correlação dos dados, que são encontrados nesse universo diversificado de informações. Para que isso se torne viável, Moran propõe a integração da TV, vídeo, Internet e seus recursos ao processo de aprendizagem. As sugestões são para que se utilize o vídeo em diferentes momentos, como para sensibilizar para um conteúdo novo, ilustrar realidades distantes do aluno, simular situações que demandam tempo ou podem ser perigosas, até mesmo para avaliar o processo de aprendizagem e a interação professoraluno. Já para o uso da Internet propõe-se uma sequiência de trabalho que envolve a criação de uma página pessoal do professor, que será referência para todas as etapas, lista dos endereços eletrônicos de todos alunos, aulas-pesquisa, que abrirão espaços para a exploração de conteúdos novos e soluções de problemas, nas quais o professor estimula a troca de informações e a comunicação dos resultados das pesquisas de todos, além de estimular a busca de informações diferentes em pesquisas dirigidas.

No capítulo 2, Behrens apresenta os paradigmas que vêm surgindo na educação, levantando a importância de aspectos como a aprendizagem colaborativa e a significativa. Apresenta quatro pontos que sustentam a aprendizagem ao longo de toda vida: aprender a conhecer, aprender a fazer, aprender a viver juntos e aprender a ser.

Comparando com o tradicional, em que o professor é transmissor de conhecimentos e o aluno é uma central de armazenamento e memória de informações, o paradigma emergente da educação envolve diferentes pressupostos de novas teorias educacionais, tais como a busca de visão de totalidade, o enfoque da aprendizagem e o desafio de superação da reprodução para a produção do conhecimento. $\mathrm{O}$ computador e a rede de informações servem como instrumentos e suportes importantes na ação docente necessária aos novos parâmetros educacionais.

Em seguida, a autora apresenta o contexto em que essa proposta pode ser inserida: projetos de trabalho. Traz, com muita clareza, as etapas e passos a serem seguidos para a realização deles, sempre integrados à tecnologia. Ela encerra este capítulo com uma conclusão muito importante acerca do objetivo da aprendizagem, envolvendo a aplicação dos conhecimentos adquiridos nos diversos contextos em que o aluno está inserido, utilizando-se da autonomia e da crítica para fazê-lo.

Masetto apresenta um panorama geral da mediação pedagógica no último capítulo, analisando tanto o 
papel do professor quanto o emprego da tecnologia como recurso, voltando a colocar o professor como orientador das atividades do aluno, visto como um consultor, assim como foi feito por Moran. Para atingir este patamar, o professor precisa desenvolver algumas características, como colocar o aluno no centro do processo de aprendizagem, percebendo suas necessidades, estabelecer parcerias com os alunos para o planejamento, realização e avaliação das atividades, estudar sempre para aprofundar-se nas informações de sua área de conhecimento, ser criativo, estar aberto ao diálogo e cuidar de sua comunicação e expressão, para se fazer entender através da máquina e atingir os diferente níveis de compreensão dos alunos.

A forma como este autor destaca a avaliação é muito bem contextualizada; comenta como é impor- tante este momento do trabalho, como sendo a etapa final da aprendizagem e, portanto, devendo ser coerente com todo o processo. O sistema de ensino e as propostas apresentadas nos capítulos deste livro sugerem uma avaliação que aproveite os recursos tecnológicos também, especialmente o computador.

Este livro é uma leitura agradável por sua forma didática de expor conceitos, traçando sempre panoramas completos para contextualizar cada aspecto envolvido na aprendizagem. É muito rico em orientações sobre como organizar os recursos tecnológicos em uma proposta educacional significativa, aplicáveis em qualquer nível de ensino.

Anna Karina Nogueira Pereira Universidade São Francisco - Itatiba S/P 